\title{
Antioxidant capacity of amaranth products: effects of thermal and enzymatic treatments
}

\author{
Caroline PAZINATTO ${ }^{1}$, Luciana Gomes MALTA ${ }^{1}$, Gláucia Maria PASTORE${ }^{1}$, Flavia Maria NETTO ${ }^{1 *}$
}

\begin{abstract}
The effect of different process -defatting, protein concentration, thermal treatment, hydrolysis with Alcalase and in vitro digestion- on the antioxidant capacity of amaranth seeds was studied. The antioxidant capacity of the products was determined in methanolic and aqueous extracts and varied from 1.00 to 21.22 and 4.97 to $369.18 \mu$ mol TE/g sample for DPPH and ORAC assays, respectively. The combination of protein concentration and hydrolysis with Alcalase led to products with higher antioxidant activity. However, after in vitro digestion, protein concentrate and its hydrolysate showed similar antioxidant capacity. A high correlation was observed between the antioxidant capacity and the total phenolic content for methanolic extracts, with $\mathrm{r}^{2}$ values ranging from 0.6133 to 0.9352 .
\end{abstract}

Keywords: gastrointestinal digestion; bioactive peptides; antioxidant compounds.

\section{Introduction}

Reactive oxygen species (ROS) are formed during metabolic processes in all living organisms, resulting from oxygen metabolism and exogenous sources, such as carcinogenic compounds and ionizing radiation (VERTUANI; ANGUSTINI; MANFREDINI, 2004). ROS (hydroxyl radical, superoxide anion and singlet oxygen) react with biomolecules such as proteins and lipids, resulting in severe damage to the cell membrane and DNA (SHAHIDI, 2009; TARKO; DUDA-CHODAK; TUSZYŃSKI, 2009). Antioxidant compounds prevent oxidative chain reactions by preventing initiation and propagation steps of the oxidation mechanism, terminating the oxygen reactions and promoting a delay in the degradation reactions (MATTHÄUS, 2002). These properties allow such molecules to act as reducing agents, hydrogen donors, singlet oxygen quenchers and metal chelators, inhibiting the oxidation of simple molecules, polymers and complex biosystems (MATTHÄUS, 2002). The consumption of dietary antioxidants improves endogenous antioxidant defense strategies against oxidative stress. Vitamins $\mathrm{E}$ and $\mathrm{C}$, carotenoids, phenolic compounds and also proteins, peptides and amino acids are known for their antioxidant properties and as coadjutants in the body defense system (SHAHIDI, 2009).

Hydrolysis has been widely used to improve the antioxidant capacity of food proteins. Peptides with antioxidant properties can be obtained from different sources such as egg, milk, fish, legumes and cereals (ELIAS; KELLERBY; DECKER, 2008; SAMARANAYAKA; LI-CHEN, 2011). Hydrolysis of food protein can be performed using exogenous or endogenous enzymes, food processing or during microbial fermentation, as well as during gastrointestinal (GI) digestion of food (SAMARANAYAKA; LI-CHEN, 2011; KORHONEN; PIHLANTO-LEPPALA, 2003). Commercial microbial or plant origin proteases have attracted great interest for the generation of food-derived functional hydrolysates and peptides due to their unique functions, wide accessibility, and cost-effectiveness. During hydrolysis, the protease specificity is crucial since it dictates the sequence and the functionality of the amino acids of the resultant peptide (SAMARANAYAKA; LI-CHEN, 2011; KORHONEN; PIHLANTO-LEPPALA, 2003).

Biologically active compounds must reach the primary site of action to be active. The first limiting factor for the bioavailability of a compound is the release from the food matrix and solubilization. In vitro digestion has been used to estimate the bioaccessibility of antioxidant compounds, such as phenolics (TARKO; DUDA-CHODAK; TUSZYŃSKI, 2009; ANSON et al., 2010) and peptides and proteins (ORSINIDELGADO; TIRONI; AÑÓN, 2011).

Amaranth is a highly nutritional pseudocereal that presents higher protein content than cereal species. Many health benefits are attributed to amaranth seeds, such as decreasing plasma cholesterol levels, stimulating the immune system, antitumor activity, reducing blood glucose levels and improving conditions of hypertension and anemia (CASELATO-SOUZA; AMAYA-FARFÁN, 2012). Concerning the antioxidant activity, Gorinstein et al. (2007) reported that amaranth, as well as other pseudocereals, has an antioxidant capacity comparable to that of soybean and rice. According to these authors, the main antioxidant compounds of pseudocereals are polyphenols, although proteins also have an important role as radical scavengers. Barba de la Rosa et al. (2009) studied distinct amaranth cultivars and identified polyphenols (isoquercetin and rutin) and phenolic acids (syringic and vanillic acids) with antioxidant capacity. Amaranth is also rich in amino acids known for antioxidant capacity, such as: sulphuric (cysteine and methionine), aromatic (tyrosine and tryptophan), lysine,

\footnotetext{
Received 29/1/2013

Accepted 22/6/2013 (006002)

${ }^{1}$ Faculdade de Engenharia de Alimentos, Universidade Estadual de Campinas - UNICAMP, Rua Monteiro Lobato, 80, CP 6121, CEP 13083-970, Campinas, SP, Brasil, e-mail:flavia@fea.unicamp.br

${ }^{*}$ Corresponding author
}

DOI: http://dx.doi.org/10.1590/S0101-20612013005000076 
histidine, proline, glycine, alanine and threonine (TIENGO; FARIA; NETTO, 2009; WANG; DE MEJIA, 2005). Tironi and Añón (2010) found naturally-occurring water soluble peptides with free radical scavenging and inhibition of the linoleic acid oxidation activities in Amaranthus mantegazzianus seeds. Aqueous extracts of A. mantegazzianus protein hydrolysates showed potential capacity to scavenge free radicals (ORSINIDELGADO; TIRONI; AÑÓN, 2011). In most of the studies on plant protein hydrolysates, the antioxidant capacities have been described using extraction with organic solvents or water when the phenolics or peptides were the aim of the study, respectively. This approach may result incomplete especially for plant protein hydrolysates, since phenolics and peptides are released during the hydrolysis and also during the processing of derived products. The aims of the present study were to investigate the effects of the protein concentration and thermal enzymatic treatments on the antioxidant capacity of Amaranthus cruentus (BR-Alegria variety) in aqueous and methanolic extracts and evaluate the stability of the antioxidant compounds to in vitro digestion.

\section{Materials and methods}

\subsection{Material}

Amaranthus cruentus seeds (BR Alegria variety) were provided by the Association of the Farmers of Ituporanga (Ituporanga-SC, Brazil). The seeds were stored at $-18{ }^{\circ} \mathrm{C}$ and evaluated 6 months after harvesting. Reagents of analytical or chromatographic grade were used.

\subsection{Methodology}

Preparation of defatted flour, protein concentrates and hydrolysates

Whole amaranth flour (WAF) was obtained by grinding the seeds in a blade-mill (model MA630, Marconi, Piracicaba-SP, Brazil). To obtain the defatted flour (DAF), WAF was defatted twice using hexane (1:3, w/v hexane: flour ratio) for 24 hours at room temperature and stored at $4{ }^{\circ} \mathrm{C}$ until use. To obtain the amaranth protein concentrate (APC), DAF was dispersed in distilled water at flour/water ratio of 1:10. The $\mathrm{pH}$ of the dispersion was adjusted to $\mathrm{pH} 9.0$ with $2.0 \mathrm{M} \mathrm{NaOH}$ and stirred for 1 hour and centrifuged $\left(9000 \mathrm{~g}, 20\right.$ minutes, $\left.4^{\circ} \mathrm{C}\right)$ to remove insoluble material. The $\mathrm{pH}$ of the supernatant was adjusted to 4.5 with $2 \mathrm{M} \mathrm{HCl}$, and centrifuged $\left(9000 \mathrm{~g}, 20\right.$ minutes, $4{ }^{\circ} \mathrm{C}$ ). The obtained precipitate was washed with distilled water and re-dispersed in distilled water with $\mathrm{pH}$ adjusted to 7.0, and centrifuged $\left(9000 \mathrm{~g}, 20\right.$ minutes, $\left.4^{\circ} \mathrm{C}\right)$. This process was repeated three times and the final dispersion was lyophilized to produce the APC.

Protein hydrolysates were produced from the DAF or APC using the enzyme Alcalase. To investigate the effect of heating on the parent material, the protein hydrolysates were prepared from untreated (DAF, APC) or previously heat-treated defatted flour (DAFht) and protein concentrates (APCht). Dispersions of the protein concentrate or defatted flour $(10 \mathrm{~g} / 100 \mathrm{~mL}$ in distilled water), untreated or heated at $90{ }^{\circ} \mathrm{C}$ for 30 minutes, were equilibrated at the reaction conditions before adding the enzyme. The hydrolysis conditions were: enzyme substrate ratio (E:S) 1:50 (w/w), $\mathrm{pH} 8.0$ and $60^{\circ} \mathrm{C}$. The reaction was monitored using a pH-stat (Mettler-Toledo DL 25 titration unit, Schwerzenbach, Switzerland), and the $\mathrm{pH}$ was maintained constant by continuous addition of $1 \mathrm{~N} \mathrm{NaOH}$. The degree of hydrolysis (DH) was calculated according to Adler-Nissen (1986). When the DH reached $12 \%$, which was close to the maximum $\mathrm{DH}$ value obtained under the conditions used in the experiment, the reaction was interrupted by heating to $90^{\circ} \mathrm{C} / 10$ minutes in a water bath, followed by cooling and centrifugation $\left(1500 \times g\right.$ for 10 minutes $/ 21^{\circ} \mathrm{C}$ ). The supernatants containing the protein hydrolysates were freeze-dried and stored at $-18^{\circ} \mathrm{C}$ for analysis. The protein content of the products was determined in triplicate by the Kjeldhal method (ASSOCIATION..., 1995), using 5.85 as the conversion factor.

\section{In vitro digestion}

In vitro digestion was carried out according to the method described by Tiengo, Faria and Netto (2009). Briefly, aqueous dispersions $(10 \% \mathrm{w} / \mathrm{v})$ of the samples were adjusted to a $\mathrm{pH}$ of 2.5 with $2 \mathrm{~N} \mathrm{HCl}$, warmed to $37^{\circ} \mathrm{C}$, and the pepsin (E:S 1:100, $\mathrm{w} / \mathrm{w}$ ) was added. After 2 hours under continuous stirring, the solution was neutralized ( $\mathrm{pH} 7.0$ ) by adding $2 \mathrm{~N} \mathrm{NaOH}$. The pancreatin (E:S 1:50, w/w) was immediately added, and after stirring for 4 hours the reaction was stopped by heating to $90^{\circ} \mathrm{C}$ for 10 minutes. The material was then centrifuged at $1500 \mathrm{~g}$ for 10 minutes at $21^{\circ} \mathrm{C}$. The supernatants containing the digested product were freeze dried and stored in sealed flasks at $-18^{\circ} \mathrm{C}$ until use.

\section{Polyacrylamide gel electrophoresis}

The molecular mass (MM) profile of the proteins was determined by using a SDS-PAGE system (LAEMMLI, 1970). Stacking and separating gels of $4 \%$ and $12 \%$ acrylamide, respectively, were used. The samples were dissolved in reducing buffer (62.5 mM Tris-HCl, pH 6.8, 2.0\% SDS, 20.0\% glycerol, $5.0 \% \beta$-mercaptoethanol and $0.1 \%$ bromophenol blue), heated to $90{ }^{\circ} \mathrm{C}$ for 30 minutes and a $10 \mu \mathrm{L}$ aliquot $(0.4 \%$ protein) was applied to each well. After the run, gels were stained with $0.1 \%$ Coomassie Blue (G-250, Merck, Darmstadt, Germany) and distained in an acetic acid/methanol/water solution at a ratio of 1:4:5. A molecular mass (MM) standard from 14 to $97 \mathrm{kDa}$ (Biorad, Hercules, CA, USA) was used as reference.

The profiles of the protein hydrolysates and digested samples were determined by SDS-PAGE-Tricine system (SCHÄGER; JAGOW, 1987) using stacking, spacer and separating gels of $4 \%, 10 \%$, and $14.6 \%$ acrylamide, respectively. The samples were dissolved in reducing buffer $(0.5 \mathrm{M}$ Tris- $\mathrm{HCl}, \mathrm{pH} 6.8,10.0 \% \mathrm{SDS}$, $10.0 \%$ glycerol, $5.0 \% \beta$-mercaptoethanol and $0.1 \%$ bromophenol blue) and heated at $40^{\circ} \mathrm{C}$ for 30 minutes. Aliquots of $20 \mu \mathrm{L}(0.4 \%$ protein $\mathrm{w} / \mathrm{v}$ for DAF and DAFht and $2 \%$ protein for the other samples) were applied to each well. The MM standard used was from 6.5 to $26.6 \mathrm{kDa}$ (Amersham-Pharmacia Biotech, Uppsala, Sweden). After the runs, gels were fixed for 1 hour in a methanol/ acetic acid/water solution at a ratio of 5:1:4, stained for 48 hours 
with G-250 Coomassie blue ( $0.4 \%$ Coomassie blue in $10 \%$ acetic acid) and distained with a $10 \%$ acetic acid solution.

\section{Extraction procedures}

The extracts used for determining the total phenolics content and antioxidant capacity (DPPH and ORAC) were obtained by using distilled water or methanol. The aqueous extracts were prepared in distilled water $\left(50 \mathrm{mg} \mathrm{mL}^{-1}\right)$, stirred for 30 minutes, centrifuged (35735 $\mathrm{x} \mathrm{g}$ at room temperature/ 15 minutes) and filtered through Whatman \# 1 filter paper. The methanolic extracts were prepared by dispersing the samples in methanol (HPLC grade, Mallinckrodt Baker, Inc. Phillisburg, NJ, USA), shaking for 10 minutes and placing in a water bath at $50{ }^{\circ} \mathrm{C}$ for 1 hour and then at $65{ }^{\circ} \mathrm{C}$ for 5 minutes. The extracts were filtered through Millipore $13 \mathrm{~mm}, 0.45 \mathrm{UM}$ PTFE membranes and stored in screw-top glass tubes at $-20^{\circ} \mathrm{C}$ until use. The extraction was carried out using product:solvent ratios (w/v) 1:5 for WAF, DAF and APC; and 1:50 for hydrolysates and samples after in vitro digestion.

\section{Total phenolics content}

The total phenolics content was determined in the aqueous and methanolic extracts using Folin-Ciocalteau reagent (FCR; Sigma Chemical Co, St. Louis, MO, EUA), according to Gamel et al. (2006). Gallic acid (3,4,5-trihydroxybenzoic acid, Sigma Chemical Co, St. Louis, MO, USA) in distilled water (0.02 to $0.12 \mathrm{mg} \mathrm{mL}^{-1}$ ) was used as standard for calibration curve and the results were expressed in gallic acid equivalents (mg GAE/g dry sample).

\section{$D P P H$ Free radical scavenging capacity (DPPH)}

The free radical scavenging activity was measured using the free radical DPPH (2,2-difenil-1-picrilhidrazil, Sigma Chemical Co, St. Louis, MO, USA) according to Thaipong et al. (2006). A stock solution of DPPH (24 mg / $100 \mathrm{~mL}$ of methanol) was stored at $-20{ }^{\circ} \mathrm{C}$. The working solution $(8.6 \mathrm{~mL}$ stock solution $/ 50 \mathrm{~mL}$ methanol) was prepared daily. An aliquot of $150 \mu \mathrm{L}$ of extract and $2.9 \mathrm{~mL}$ of the working DPPH solution were mixed and after 24 hours of reaction in the dark the absorbance was measured at $515 \mathrm{~nm}$. The standard curve was prepared using Trolox ((R)(+)-6-hidroxy-2,5,7,8-tetramethylcroman-2-carboxylic acid, Sigma Chemical Co) in methanol at concentrations from 25 to $935 \mu \mathrm{M}$. The results were expressed in Trolox equivalents ( $\mu \mathrm{mol}$ TE/g dry sample).

\section{Oxygen radical absorbance capacity (ORAC)}

The ORAC assay was carried out according to the methodology described by Dávalos, Gómez-Córdovés and Bartolomé (2004) with adaptations. The determination was performed using a Fluostar Optima plate reader (BMG Labtech, Durham, NC) with fluorescein filters (485 $\mathrm{nm}$ excitation wavelength; $520 \mathrm{~nm}$ emission wavelength). Fluorescein (sodium fluorescein; VETEC Química Fina LTDA., Duque de Caxias, RJ, Brazil) was used as the probe and AAPH (2.2' -azobis (2-methylpropionamidine) dihydrochloride (Sigma Chemical
Co. $)$ as the radical generator. The fluorescein $(0.378 \mu \mathrm{g} / \mathrm{mL}$ in phosphate buffer, $\mathrm{pH} 7.4)$ was added $(120 \mu \mathrm{L})$ into the wells containing $20 \mu \mathrm{L}$ of extract (final concentration $1 \mathrm{mg} / \mathrm{mL}$ ) or standards. AAPH was dissolved in water (final concentration $108 \mathrm{mg} / \mathrm{mL}$ ) and $60 \mu \mathrm{L}$ was injected into the wells. The AAPH solution was prepared immediately before use. A blank was prepared by replacing the extract by phosphate buffer. The fluorescence was recorded every minute for 80 minutes. The equipment was at $37^{\circ} \mathrm{C}$ and each sample was read in triplicate. A new standard curve (0.1-100 $\mu \mathrm{M}$ Trolox in phosphate buffer) was obtained every day.

AUC (area under the curve) was calculated by using the fluorescence readings, where the $\mathrm{x}$ axis corresponds to time and the $y$ axis to the decrease in fluorescence. The blank AUC was subtracted from AUC of each sample and standard. The AUC of the samples were then calculated by the equation obtained with the Trolox standard curve (0.1-100 $\mu \mathrm{M}$ Trolox) and the values were expressed in Trolox equivalents ( $\mu \mathrm{mol} \mathrm{TE/g} \mathrm{dry} \mathrm{sample).}$

\section{Statistical analysis}

Results are expressed as the mean \pm standard deviation. The results for the total phenolics content and antioxidant capacity were obtained from two extracts, analyzed in triplicate. The data were tested by one-way ANOVA and the significant differences between the means for the values were evaluated by Tukey's Test at $5 \%$ level of significance. Pearson correlation coefficients and $\mathrm{p}$-values were used to show correlations and significance. Data were analyzed using SAS Statistical Analyses System software (version 9.1.3, 2003, N.C., USA).

\section{Results and discussion}

The WAF and DAF showed $13.7 \pm 0.3$ and $14.7 \pm 0.3 \mathrm{~g}$ of protein $/ 100 \mathrm{~g}$ solids, and $6.4 \pm 0.1$ and $0.9 \pm 0.3 \mathrm{~g}$ of lipids $/ 100 \mathrm{~g}$ solids, respectively, indicating partial defatting. The APC showed $75.1 \pm 0.9 \mathrm{~g}$ of protein/100 g solids and $4.6 \pm 0.1 \mathrm{~g}$ of lipids/100 g solids and presented higher protein content than reported for the protein concentrate of A. hypochondriacus (64\%) obtained under the same $\mathrm{pH}$ in the extraction and precipitation steps (PAREDES-LÓPEZ; MORA-ESCOBEDO; ORDORICA-FALOMIR, 2006).

\subsection{Electrophoretic characterization}

The electrophoretic profiles (SDS-PAGE) of the flours and protein concentrates before and after thermal treatment $\left(90^{\circ} \mathrm{C} / 30 \mathrm{~min}\right.$ ) were similar to those found for the protein concentrates and amaranth isolates (Figure 1A). The fractions with MM between 20 and $43 \mathrm{kDa}$ corresponded to the $7 \mathrm{~S}$ and $11 \mathrm{~S}$ globulins and the fractions between 43 and $67 \mathrm{kDa}$ to the glutelin, a protein fraction found in smaller quantities in amaranth proteins (GAMEL et al., 2005). All the samples exhibited bands in the $14 \mathrm{kDa}$ region, which were weaker in the APCht profile (Figure 1A, lane 6), suggesting that the thermal treatment may cause changes in these fractions.

Whereas not all the flour protein fractions were present in the protein concentrates, the hydrolysates were obtained 


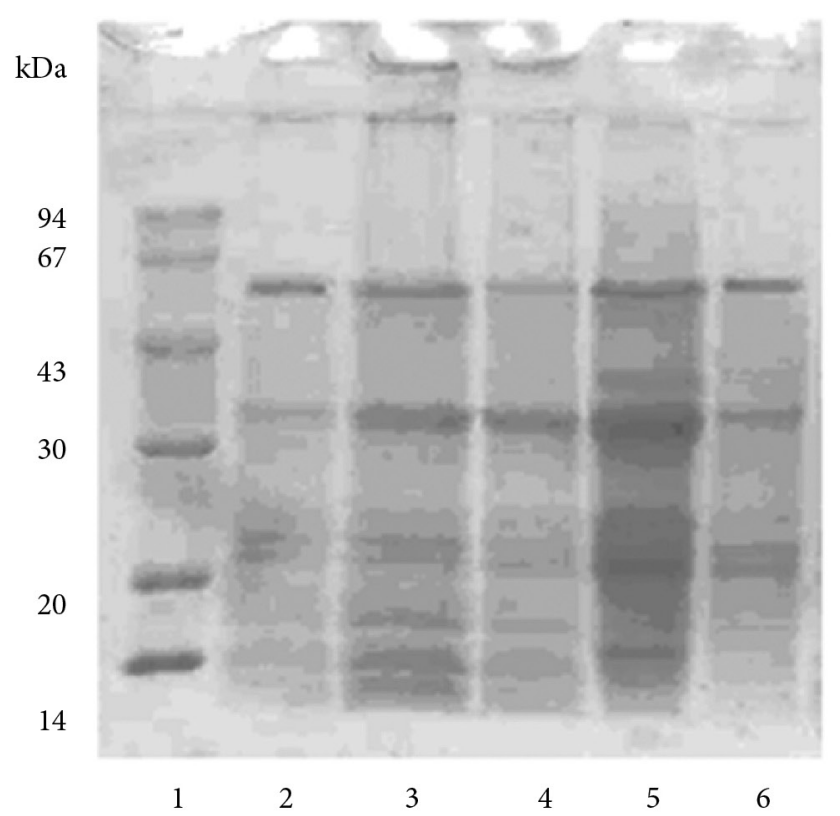

B

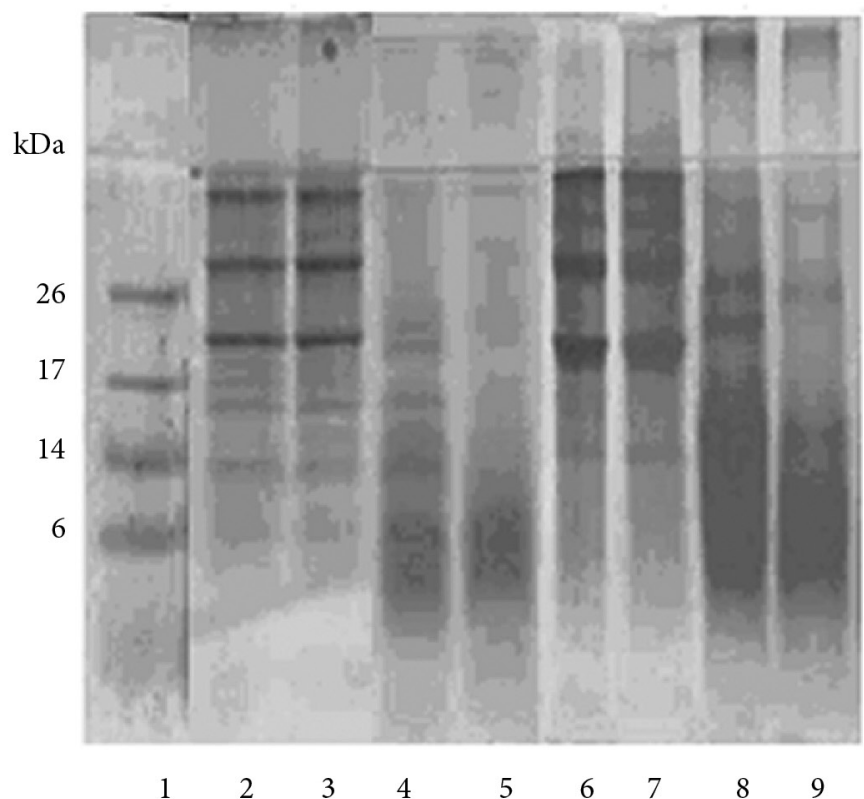

Figure 1. (A) SDS-PAGE Electrophoresis of DAF, APC and hydrolysates. Lanes: 1- molecular mass standards; 2- whole amaranth flour (WAF); 3- defatted amaranth flour (DAF); 4- heat-treated DAF (DAFht); 5- amaranth protein concentrate (APC); 6- heat-treated APC (APCht). Aliquot of $10 \mu \mathrm{L}(0.4 \%$ protein) was applied to each well. (B) SDS-PAGE Tricine electrophoresis of DAF, APC and hydrolysates. Lanes: 1- MM standard; 2- defatted amaranth flour (DAF); 3- heat-treated DAF (DAFht); 4- DAF hydrolyzed with Alcalase (HDAF); 5- DAFht hydrolyzed with Alcalase (HDAFht); 6- amaranth protein concentrate (APC); 7- heat-treated APC (APCtt); 8- APC hydrolyzed with Alcalase (HAP); 9 - APCht hydrolyzed with Alcalase (HAPht). Aliquot of $20 \mu \mathrm{L}$ was applied to each well. The protein concentration for DAF and DAFht samples was $0.4 \%$; for the other samples, $2 \%$.

from the DAF and also from the APC. Furthermore, before the enzymatic hydrolysis the parent materials were heat-treated, since proteins with different degrees of denaturation subjected to the same hydrolysis conditions may release different peptides (ADLER-NISSEN, 1986).

Figure 1B shows the electrophoretic profiles of the hydrolysates (SDS-PAGE-Tricine) and of their parent proteins. After hydrolysis with Alcalase, the bands with MM above $26 \mathrm{kDa}$ obtained for the DAF disappeared, while a large and diffuse band in the region below $14 \mathrm{kDa}$ was formed, indicating that the Alcalase hydrolyzed the original fractions and led to the formation of low MM peptides. The bands with MM above $14 \mathrm{kDa}$ present in the hydrolysate of DAF (HDAF) could not be observed in the HDAFht profile, suggesting that the thermal treatment facilitated the hydrolysis of the flour. The hydrolysate profiles of the protein concentrates presented attenuated bands with $\mathrm{MM}$ above $26 \mathrm{kDa}$ and two bands in the $26 \mathrm{kDa}$ region, but only one of these bands was observed in the HAPht profile. As a consequence of the hydrolysis, an intense and diffuse band with MM below $17 \mathrm{kDa}$ appeared. The Alcalase hydrolysates from the APC showed fractions and peptides with MM up to $14 \mathrm{kDa}$ while those from DAF showed only faint higher MM bands.

\subsection{In vitro digestion}

The in vitro digestion of the amaranth flours, concentrates and protein hydrolysates was carried out to evaluate the effect of the gastrointestinal enzymes on the protein fractions and the phenolic compounds released from the food matrix, as well as on the antioxidant capacity of the products.

The electrophoretic profiles of the digested materials from all of the samples (Figure 2) showed that the action of the GI enzymes cleaved the fractions above $17 \mathrm{kDa}$, with the concomitant release of low MM peptides, except for the digested DAFht (Figure 2, lane 3), in which a weak band above $26 \mathrm{kDa}$ was observed. This finding suggests that thermal treatment led to aggregates, which were partially or not digested by gastrointestinal enzymes.

\subsection{Total phenolics}

Total phenolics content in the aqueous (1.5-28.2 mg GAE/g sample) was higher than in the methanolic extracts $(0.5-22.6 \mathrm{mg}$ GAE/g sample) (Table 1). It should be noted that the FCR is not specific for phenolic compounds and can be reduced by other compounds such as tertiary aliphatic amines, ascorbic acid, $\mathrm{Cu}$ (I), sugars, aromatic amino acids (tryptophan, phenylalanine and tyrosine) amongst others (HUANG; OU; PRIOR, 2005). Thus, the values reported for phenolic contents in aqueous extracts, besides water soluble phenolics, can also include sugars, proteins, peptides and amino acids released by the protein concentration process and particularly by the hydrolysis with Alcalase and in vitro digestion (TARKO; DUDA-CHODAK; TUSZYŃSKI, 2009; MATTHÄUS, 2002; GAHLER; OTTO; BÖHM, 2003; MICHALSKA; CEGLINSKI; ZIELINSKI, 2007). Matthäus (2002) observed similar behavior for oilseeds. Solvents 
Table 1. Total phenolic content in flours, protein concentrates and protein hydrolysates of Amaranthus cruentus, before and after in vitro digestion ${ }^{\mathrm{a}}$.

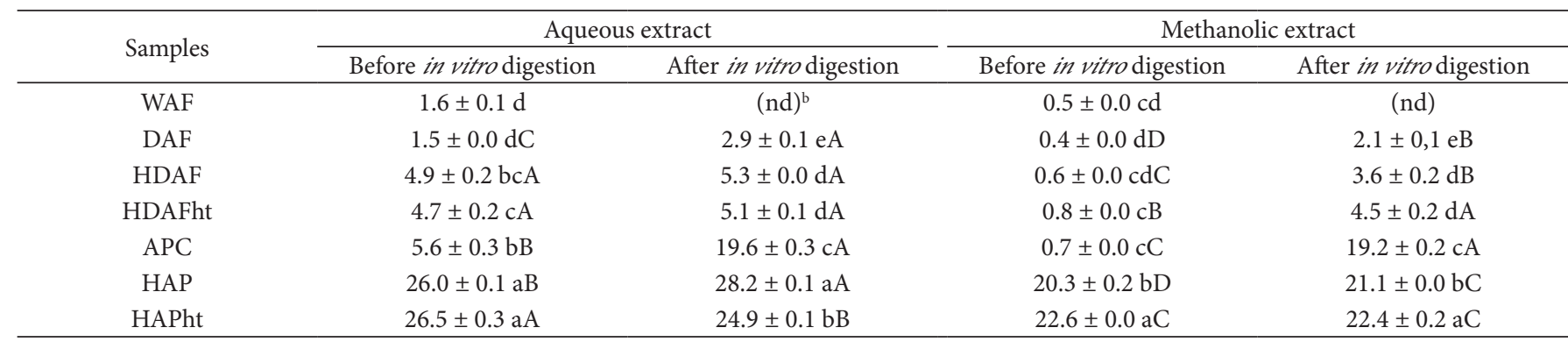

${ }^{\mathrm{a}}\left(\mathrm{mg}\right.$ gallic acid equivalent $\mathrm{g}^{-1}$ sample) (nd) non-determined; ${ }^{\mathrm{b}}\left(\mathrm{mg}\right.$ gallic acid equivalent $\mathrm{g}^{-1}$ sample); Different lower case letters in same column and different capital letters in same row (same extract) indicate significant statistical difference $(\mathrm{p}<0.05)$. WAF $=$ whole amaranth flour; DAF= defatted amaranth flour; HDAF= defatted amaranth flour hydrolyzed with Alcalase; HDAFht= heat-treated defatted amaranth flour hydrolyzed with Alcalase; APC = amaranth protein concentrate; $\mathrm{HAP}=\mathrm{APC}$ hydrolyzed with Alcalase; HAPht= heat-treated APC hydrolyzed with Alcalase.

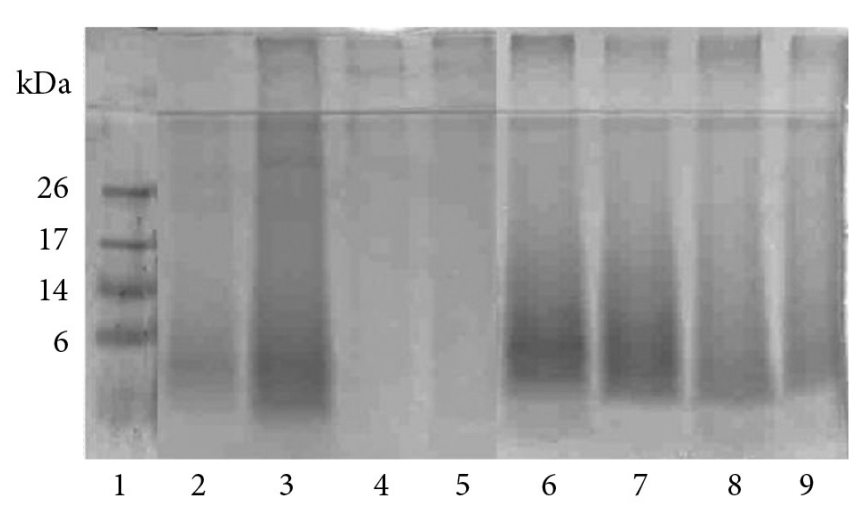

Figure 2. SDS-PAGE Tricine electrophoresis of the samples after in vitro digestion. Lane 1- molecular mass standards; digested from: 2defatted amaranth flour (DADF); 3: -heat-treated defatted amaranth flour (DADFht); 4- defatted amaranth flour hydrolyzed with Alcalase (DHDAF); 5- heat-treated defatted amaranth flour hydrolyzed with Alcalase (DHDAFht); 6- amaranth protein concentrate (DAPC); 7heat-treated amaranth protein concentrate (DAPCht); 8- amaranth protein concentrate hydrolyzed with Alcalase (DHAP); 9- heat-treated amaranth protein concentrate hydrolyzed with Alcalase (DHAPht). Aliquot of $20 \mu \mathrm{L}$ ( $2 \%$ protein) was applied to each well.

with different polarities cause differences not only regarding the phenolic compounds extracted but also with respect to the antioxidant capacity found in the extracts (MATTHÄUS, 2002; GORINSTEIN et al., 2007).

The total phenolic content in the flours (WAF and DAF) and APC was 0.4 to $5.6 \mathrm{mg} \mathrm{GAE} / \mathrm{g}$ sample and within the range of values reported for amaranth in the literature, which varied from 0.15 to $5.24 \mathrm{mg} \mathrm{GAE/g} \mathrm{sample} \mathrm{(GORINSTEIN} \mathrm{et} \mathrm{al.,} \mathrm{2007;}$ GAMEL et al., 2006). The protein concentration processing to obtain the APC resulted in phenolic concentration almost four times higher while it was reported that the most common methods for processing amaranth grains-cooking, popping, and extrusion -reduced the mean total phenolics content in amaranth grain (QUEIROZ et al., 2009).

The hydrolysate of DAF (HDAF) with Alcalase showed the same range of values (4.9 and $0.6 \mathrm{mg} \mathrm{GAE} / \mathrm{g}$ sample in the aqueous and methanolic extracts, respectively) whereas the hydrolysates with Alcalase from APC showed values five or more times higher than those obtained from the flour. These results indicate that the hydrolysis with Alcalase after the protein concentration process released compounds which react with FCR more efficiently than when it acts directly on the flour. The flour has a more complex matrix and lower protein and phenolics compounds contents than the APC, thus reactive compounds were found in lower concentration. Once the phenolic compounds can be linked to the other food components in different ways, the release process from distinct matrices can be different (JEONG et al., 2004). These compounds commonly linked to the cell wall polymers by covalent bonds may be released by treatments with alkalis, acids and enzymes (MICHALSKA; CEGLINSKI; ZIELINSKI, 2007).

An increase in total phenolics was revealed after the simulated digestion for all samples. The in vitro digestion of DAF increased the phenolic contents in the methanolic (2 times) and aqueous (5 times) extracts and a very significant increase was observed for APC in the methanolic extract (27 times). These findings suggest that both the gastrointestinal enzymes and the $\mathrm{pH}$ shifting might generate reactive compounds. However, for the hydrolysates with Alcalase only a slight or no increase at all was observed after digestion, indicating that no water or methanolic-soluble FCR reactive compounds were further released by the GI enzymes.

The thermal treatment $\left(90^{\circ} \mathrm{C} / 30 \mathrm{~min}\right)$ of DAF or APC performed before the hydrolysis with Alcalase caused no significant changes in the total phenolics of most samples. As found by Gamel et al. (2006) and Queiroz et al. (2009), flours from cooked and popped amaranth seeds presented lower phenolic contents than untreated amaranth seeds, while other studies showed an increase of total phenolic content in heattreated samples (GAHLER; OTTO; BÖHM, 2003; JEONG et al., 2004).

\subsection{DPPH radical-scavenging capacity}

The DPPH radical-scavenging ability of the samples is shown in Table 2. All of the amaranth products analyzed were able to react with free radicals and convert them into 
stable products. The WAF and DAF showed similar antioxidant capacity, suggesting that the reduction of the lipophilic compounds did not affect their ability to reduce the DPPH radical. In general, the hydrolysis with Alcalase significantly increased the scavenging ability of the flours ( 2 times) and APC ( $\sim 3$ to 5 times) evaluated in both solvent systems. The antioxidant capacity of the Alcalase hydrolysates from previously heat-treated material was lower than that of the hydrolysates obtained from untreated materials $(\mathrm{p}<0.05)$. This reduction in DPPH scavenging capacity may be related to the thermal treatment, which resulted in protein denaturation and in protein-protein and/or protein-phenolic interactions, leading to a different pattern of phenolic compounds and/or peptides released during hydrolysis (TSAI; SHE, 2006).

The in vitro digestion with gastrointestinal enzymes of the DAF, APC and Alcalase hydrolysates resulted in large increase in the antioxidant capacity, especially for the APC and its hydrolysates, which increased more than 7 times, assuming the highest values. Digestive enzymes were able to modify the chemical structure of soluble and insoluble materials allowing the releasing and/or exposing on the surface of the matrix, thus exerting their reducing properties. These results are important, once increasing antioxidants intake does not necessarily increase its concentration in blood and tissues, which depends mainly on the digestion mechanism and dietary assimilation (TARKO; DUDA-CHODAK; TUSZYŃSKI, 2009).

In general, the methanolic and aqueous extracts showed different DPPH scavenging capacity. For the DAF and its hydrolysates and for the APC, the aqueous extracts exhibited equal or higher antioxidant capacity than the methanolic extracts. For the APC hydrolysates the opposite was observed: the methanolic extracts presented values twice as high as the aqueous extracts. In vitro digestion of the samples changed this scenario: the methanolic extracts showed higher antioxidant capacity than the aqueous extracts, which was more significantly in the APC extracts and its hydrolysates. These differences may have been caused by interfering compounds or by the solvent itself during the extraction process. These results can be explained by the interaction of the antioxidant compounds with the solvent and/or by the solubility of the compounds. It is expected that the aqueous extracts include proteins and peptides released by hydrolysis with Alcalase and/or by the gastrointestinal enzymes. Water soluble peptides may have lower solubility in less polar solvents and compromised their electron donating ability towards the lipophilic DPPH radical (SAMARANAYAKA; LI-CHEN, 2011). On the other hand, methanol extracts contain mainly hydrophobic compounds such as phenolics and hydrophobic amino acids and peptides.

\subsection{ORAC}

All samples showed antioxidant protection against peroxide radicals. The ORAC values varied from approximately 9 to $370 \mu \mathrm{mol} \mathrm{TE} / \mathrm{g}$, depending on the treatment and the extraction solvent (Table 3). As observed in the DPPH evaluation, defatting had no influence on the antioxidant capacity of the flour. APC showed an ORAC value 8 times higher than that of DAF when

Table 2. DPPH radical-scavenging capacity ${ }^{\mathrm{a}}$ of flours, concentrates and protein hydrolysates of Amaranthus cruentus, before and after in vitro digestion ${ }^{\mathrm{a}}$.

\begin{tabular}{ccccccc}
\hline \multirow{2}{*}{ Samples } & \multicolumn{2}{c}{ Aqueous extract } & & \multicolumn{2}{c}{ Methanolic extract } \\
\cline { 2 - 3 } \cline { 5 - 6 } & Before in vitro digestion & After in vitro digestion & & Before in vitro digestion & After in vitro digestion \\
WAF & $2.22 \pm 0.00 \mathrm{e}$ & $(\mathrm{nd})^{\mathrm{b}}$ & & $1.60 \pm 0.03$ & $(\mathrm{nd})$ \\
DAF & $1.98 \pm 0.00 \mathrm{eC}$ & $2.48 \pm 0.03 \mathrm{cB}$ & & $1.48 \pm 0.01 \mathrm{cD}$ & $4.08 \pm 0.07 \mathrm{eA}$ \\
HDAF & $4.21 \pm 0.06 \mathrm{cB}$ & $4.43 \pm 0.08 \mathrm{bB}$ & & $3.00 \pm 0.15 \mathrm{bB}$ & $5.39 \pm 0.03 \mathrm{dA}$ \\
HDAFtt & $2.95 \pm 0.04 \mathrm{~dB}$ & $4.02 \pm 0.14 \mathrm{bA}$ & & $1.00 \pm 0.01 \mathrm{dC}$ & $4.00 \pm 0.04 \mathrm{eA}$ \\
APC & $2.27 \pm 0.04 \mathrm{eC}$ & $12.17 \pm 0.21 \mathrm{aB}$ & & $2.72 \pm 0.01 \mathrm{bC}$ & $19.70 \pm 0.04 \mathrm{bA}$ \\
HAP & $7.97 \pm 0.19 \mathrm{aD}$ & $12.46 \pm 0.03 \mathrm{aC}$ & & $14.98 \pm 0.01 \mathrm{aB}$ & $21.22 \pm 0.21 \mathrm{aA}$ \\
HAPtt & $7.08 \pm 0.12 \mathrm{bD}$ & $12.20 \pm 0.08 \mathrm{aC}$ & & $14.82 \pm 0.17 \mathrm{aA}$ & $13.78 \pm 0.19 \mathrm{cB}$ \\
\hline
\end{tabular}

${ }^{a} \mathrm{DPPH}$ radical-scavenging capacity antioxidant activity expressed as $\mu \mathrm{mol} \mathrm{TE} \mathrm{g}^{-1}$ sample; ${ }^{\mathrm{b}}$ non-determined. Different small case letters in the same column and capital letters in the same row indicate significant statistical difference $(\mathrm{p}<0.05)$.

Table 3. Peroxyl radical-scavenging capacity (ORAC value $)$ in flours, concentrates and protein hydrolysates of Amaranthus cruentus before and after in vitro digestion.

\begin{tabular}{ccccccc}
\hline \multirow{2}{*}{ Samples } & \multicolumn{2}{c}{ Aqueous extract } & & \multicolumn{2}{c}{ Methanolic extract } \\
\cline { 2 - 3 } \cline { 5 - 6 } & Before in vitro digestion & After in vitro digestion & & Before in vitro digestion & After in vitro digestion \\
\hline WAF & $8.92 \pm 0.79 \mathrm{e}$ & $(\mathrm{nd})^{\mathrm{b}}$ & & $12.27 \pm 1,44$ & $(\mathrm{nd})$ \\
DAF & $9.95 \pm 0.36 \mathrm{eC}$ & $110.13 \pm 2.59 \mathrm{abA}$ & & $13.47 \pm 1.37 \mathrm{cC}$ & $29.22 \pm 1.62 \mathrm{~dB}$ \\
HDAF & $60.70 \pm 3.77 \mathrm{~dB}$ & $83.09 \pm 2.51 \mathrm{bA}$ & & $17.71 \pm 1.34 \mathrm{cC}$ & $18.76 \pm 2.23 \mathrm{dC}$ \\
HDAFtt & $122.77 \pm 11.94 \mathrm{bA}$ & $25.71 \pm 2.15 \mathrm{cB}$ & & $14.64 \pm 0.07 \mathrm{cB}$ & $4.97 \pm 0.50 \mathrm{~dB}$ \\
APC & $82.13 \pm 2.64 \mathrm{cC}$ & $129.82 \pm 1.05 \mathrm{aB}$ & & $18.38 \pm 0.61 \mathrm{cD}$ & $213.91 \pm 6.84 \mathrm{cA}$ \\
HAP & $139.80 \pm 4.26 \mathrm{aC}$ & $152.46 \pm 11.42 \mathrm{aC}$ & & $212.18 \pm 19.81 \mathrm{bB}$ & $279.17 \pm 7.78 \mathrm{bA}$ \\
HAPtt & $135.99 \pm 4.81 \mathrm{abC}$ & $127.35 \pm 2.16 \mathrm{aC}$ & & $282.60 \pm 3.83 \mathrm{aB}$ & $369.18 \pm 20.93 \mathrm{aA}$ \\
\hline
\end{tabular}

${ }^{\mathrm{a}}$ ORAC value expressed as $\mu \mathrm{mol} \mathrm{TE} \mathrm{g}^{-1}$ sample; ${ }^{\mathrm{b}}$ non-determined. Different small case letters in the same column and capital letters in the same row indicate statistical difference ( $\mathrm{p}<0.05$ ). 
the aqueous extracts were evaluated but only $30 \%$ higher when the methanol extract was evaluated. After hydrolysis with Alcalase, an increase of up to 13 times (HDAFht) occurred for the antioxidant capacity against peroxyl radicals when the aqueous extracts were evaluated. The hydrolysis of APC with Alcalase increased the ORAC value 15 times when evaluated using the methanolic extract, but did not increase the ORAC value for DAF.

In vitro digestion increased the hydroxyl radical-scavenging capacity in relation to the original samples. The scavenging capacity of DAF showed an increase ( 10 times) in the ORAC value after digestion when evaluated in the aqueous extract. The APC after digestion showed an increase of 1.5 times in the aqueous extract and approximately 11 times in the methanolic extract. The Alcalase hydrolysates from DAF or APC showed small increases in the ORAC values after in vitro digestion when evaluated with both solvents. The hydrolysates from APC showed a slight significant increase only for the methanolic extract.

The DAF hydrolysates before and after in vitro digestion showed higher ORAC values in the aqueous than in the methanolic extracts, while the APC and their hydrolysates showed a higher ORAC value in the methanolic extract after in vitro digestion. The antioxidant capacity of hydrolysates is related to the amino acid composition and its sequence and to the size of the peptides released after hydrolysis (WANG et al., 2007). Moreover, according to Pérez-Jiménez and SauraCalixto (2006), some carbohydrates, proteins and amino acids can considerably increase the antioxidant effect of phenolic compounds, even when not presenting any individual activity, which can overestimate the antioxidant capacity of the phenolic compounds existing in food.

The results suggest that low MM peptides derived from in vitro digestion as well as the phenolic compounds released are important antioxidants as evaluated by the ORAC assay. These results are in agreement with Gorinstein et al. (2007), who pointed out that the main antioxidants in pseudocereals are polyphenols, although proteins also play an important role in the antioxidant activity, with an effective influence against free radicals and inhibition of lipid peroxidation. The antioxidant capacity and total phenolics evaluated in the methanolic extracts were higher than those obtained in the aqueous extracts in both the DPPH and ORAC assays. The highest antioxidant capacity shown by the enzyme-treated products, with Alcalase and/or gastrointestinal enzymes, can be explained by the release of low MM peptides and phenolic compounds, which are considered to be the main antioxidant compounds in food (GORINSTEIN et al., 2007; BARBA DE LA ROSA et al., 2009). However, the presence of different compounds seems to affect the antioxidant capacity of foods. Pérez-Jiménez and Saura-Calixto (2006) observed that some carbohydrates and amino acids are able to potentiate the antioxidant effect of phenolic compounds, although unable to exert this effect individually. The opposite also occurs when the capacity of certain antioxidant compounds is reduced when combined with other phenolic compounds (PÉREZ-JIMÉNEZ; SAURACALIXTO, 2006).

\subsection{Correlation between antioxidant capacity and total phenolic content}

Regression analysis using the Pearson correlation coefficients $\left(\mathrm{r}^{2}\right)$ indicated that the antioxidant activity as measured by the DPPH and ORAC assays is positively correlated with the FCR reactive compounds $(\mathrm{p}<0.05)$ (Figure 3$)$. The correlation between the phenolics and the DPPH values determined in the aqueous extract was higher than in the case of the ORAC values, and the contrary was observed for the methanolic extracts. It should be noted that FCR assay which was used for phenolic quantification is based on electron-transfer reaction as is DPPH, thus a good correlation would be expected (ALVAREZJUBETE et al., 2010), whereas ORAC assay involves hydrogen atom-transfer reaction. Both methods have better relationship with the compounds extracted in methanol than in the aqueous system. However, the impact of these differences was lower for the DPPH assays, as the $\mathrm{r}^{2}$ values obtained for the aqueous and methanolic extracts ( 0.7848 and 0.8865 , respectively) were closer to each other than those obtained for the ORAC assay (0.6133 and 0.9352 , respectively). Conversely, Nsimba, Kikuzaki and Konishi (2008) observed a low correlation $\left(\mathrm{r}^{2}\right.$ 0.2 ) between the phenolics content and antioxidant activity (DPPH) of ethanolic extracts from quinoa and amaranth seeds and suggested that the main antioxidants in these samples were not phenolic compounds. The correlation discrepancies could be explained by individual methods and/or presence of interfering substances. Additionally, the antioxidant activity of a substance can vary from method to method depending on factors such as antioxidant solubility, oxidation state, medium $\mathrm{pH}$ and type of oxidation-prone substrate (ALVAREZ-JUBETE et al., 2010). The samples with low phenolic contents in the aqueous extracts (DAF and its hydrolysates) showed considerable variation with respect to the ORAC values, while this fact was not observed for the DPPH, which led to a lower correlation. This behavior could be explained by the presence of non-phenolic compounds such as peptides with different sizes and structures, proteins and sugars, amongst others, which may have greater impact on the ORAC results. ORAC assay was capable of responding to a larger range of antioxidant compounds, including the protein fraction, than other methods (ZULUETA; ESTEVE; FRÍGOLA, 2009). This finding was reflected in the $r^{2}$ values obtained for the correlation between DPPH and ORAC results, 0.5211 and 0.7982 for the aqueous and methanol extracts, respectively (Figure 3). The lower value found for the aqueous extract emphasizes that the water-soluble compounds have different impacts for ORAC and DPPH assays.

\section{Conclusions}

Defatting the whole flour had no impact on its antioxidant capacity, indicating that the main antioxidant compounds of amaranth are not in the lipid fraction. All of the amaranthderived products showed antioxidant capacity as evaluated by the DPPH and ORAC. The process used to obtain the protein concentrate and the hydrolysis with Alcalase increased the antioxidant capacity mainly in methanolic extracts possibly due to the phenolic compounds release as well as the formation of low MM peptides with hydrophobic characteristic. The increase 
A

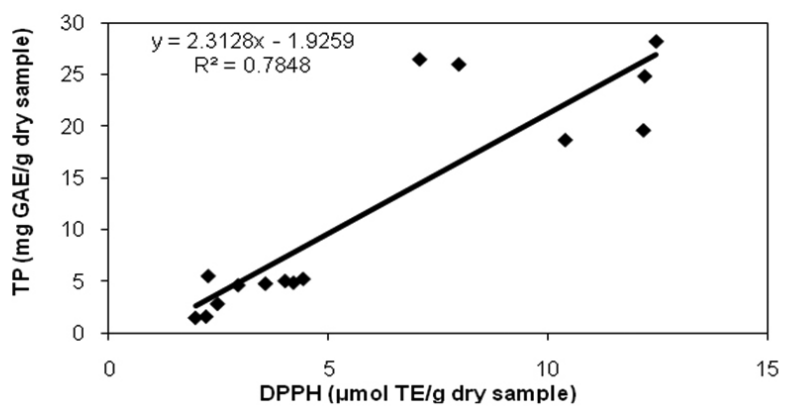

C

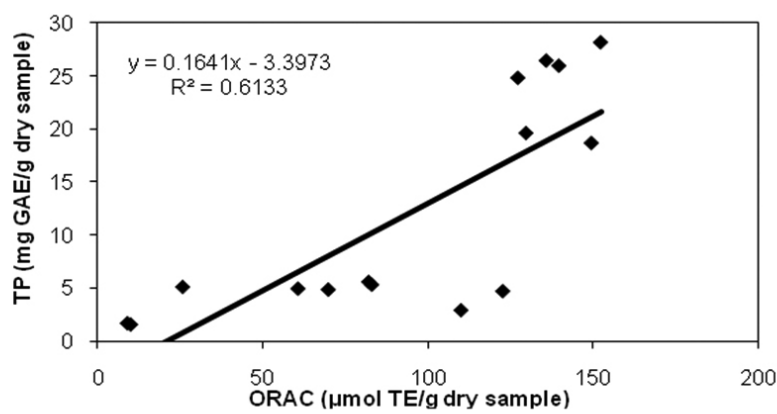

E

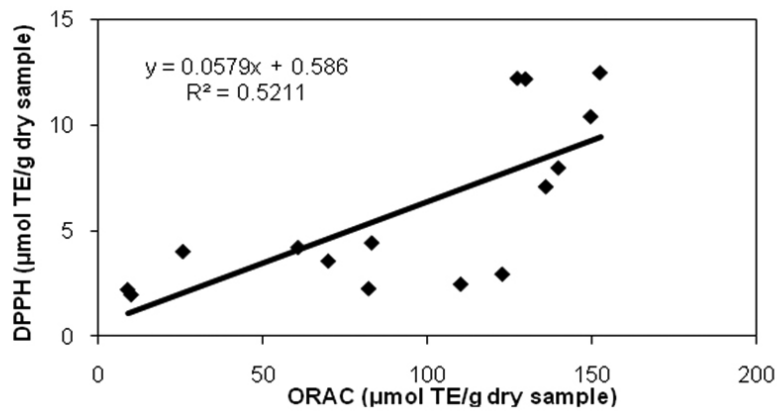

B

METHANOLIC EXTRACT

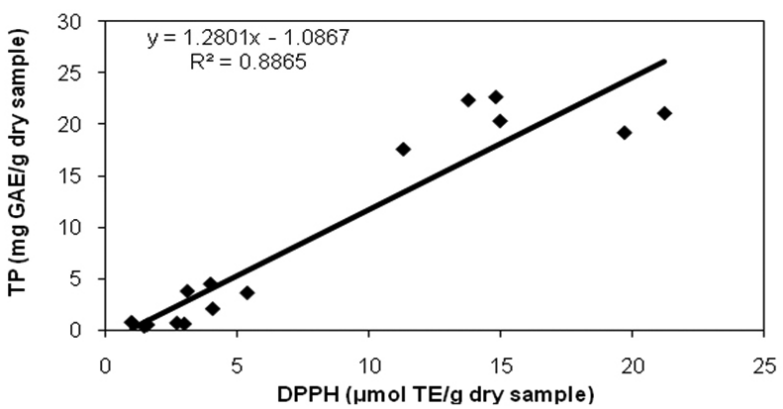

D

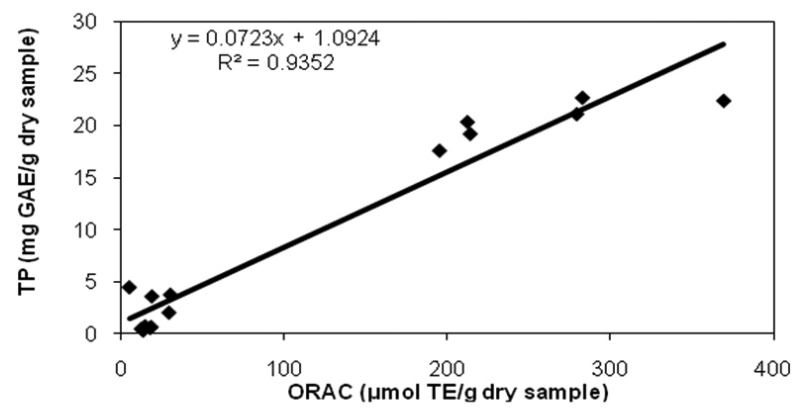

F

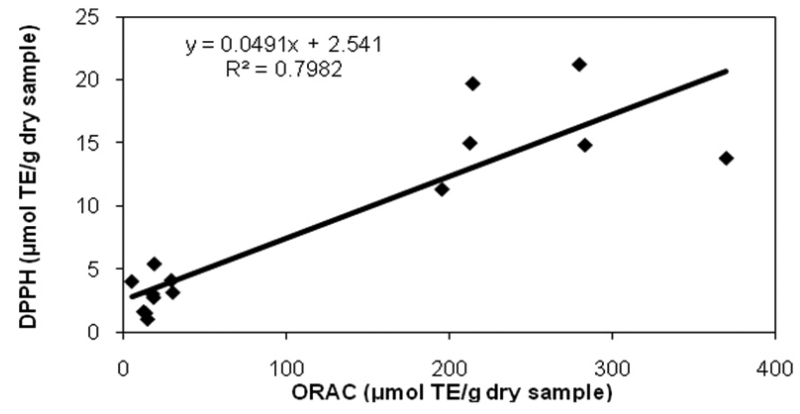

Figure 3. A-D: Correlation between the antioxidant capacity measured with aqueous or methanolic extracts by DPPH or ORAC methods and the total phenol content $(\mathrm{n}=15)$; E-F: Correlation between the results obtained by DPPH and ORAC methods $(\mathrm{n}=15)$.

in antioxidant capacity of the samples after in vitro digestion, mainly for the protein concentrate, suggests that the same can occur during physiological processes, indicating the high potential of amaranth seeds and their protein-rich products as a source of functional ingredients. The combination of the protein concentration and hydrolysis with Alcalase led to the highest antioxidant activities. However, after in vitro digestion, APC and its hydrolysates showed results in the same range of values, which suggest that the hydrolysis with Alcalase would not improve the antioxidant activity of the protein concentrate under physiological conditions.

\section{Acknowledgements}

The authors are grateful to FAPESP for financial support. C. Pazinatto thanks CAPES for scholarship.

\section{References}

ASSOCIATION OF OFFICIAL ANALYTICAL CHEMISTRY - AOAC. Official methods of analysis.15th ed. Washington: AOAC, 1995.

ADLER-NISSEN, J. Enzymatic hydrolysis of food proteins. London: Elsevier Applied Science, 1986. 427 p.

ALVAREZ-JUBETE, L. et al. Polyphenol composition and in vitro antioxidant activity of amaranth, quinoa buckwheat and wheat as affected by sprouting and baking. Food Chemistry, v. 119, n. 2, p. 770-778, 2010. http://dx.doi.org/10.1016/j.foodchem.2009.07.032

ANSON, N. M. et al. Antioxidant and anti-inflammatory capacity of bioaccessible compounds from wheat fractions after gastrointestinal digestion. Journal of Cereal Science, v. 5, n. 1, p. 110-114, 2010. http://dx.doi.org/10.1016/j.jcs.2009.10.005

BARBA DE LA ROSA, A. P. et al. Amaranth (Amaranthus hypocondriacus) as an alternative crop for sustainable food production: Phenolic acids and flavonoids with potential impact 
on its nutraceutical quality. Journal of Cereal Science, v. 49, n. 1, p. 117-121, 2009. http://dx.doi.org/10.1016/j.jcs.2008.07.012

CASELATO-SOUZA, V. M.; AMAYA-FARFÁN, J. State of Knowledge on Amaranth Grain: A Comprehensive Review. Journal of Food Science, v. 77, n. 4, p. R93-R104, 2012. PMid:22515252. http:// dx.doi.org/10.1111/j.1750-3841.2012.02645.x

DÁVALOS, A.; GÓMEZ-CÓRDOVÉS, C.; BARTOLOMÉ, B. Extending applicability of the Oxygen Radical Absorbance Capacity (ORACFluorescein) Assay. Journal of Agricultural and Food Chemistry, v. 52, n. 1, p. 48-54, 2004. PMid:14709012. http://dx.doi.org/10.1021/ jf0305231

ELIAS, R. J.; KELLERBY, S. S.; DECKER, E. A. Antioxidant activity of proteins and peptides. Critical Reviews in Food Science and Nutrition, v. 48, n. 5, p. 430-441, 2008 PMid:18464032. http:// dx.doi.org/10.1080/10408390701425615

GAHLER, S.; OTTO, K.; BÖHM, V. Alterations of vitamin C, total phenolics, and antioxidant capacity as affected by processing tomatoes to different products. Journal of Agricultural and Food Chemistry, v. 51, n. 27, p. 7962-7968, 2003. PMid:14690380. http:// dx.doi.org/10.1021/jf034743q

GAMEL, T. H. et al. Seed treatments affect functional and antinutritional properties of amaranth flours. Journal of the Science of Food and Agriculture, v. 86, n. 7, p. 1095-1102, 2006. http://dx.doi. org/10.1002/jsfa.2463

GAMEL, T. H. et al. Effect of seed treatments on the chemical composition and properties of two amaranth species: starch and protein. Journal of the Science of Food and Agriculture, v. 85, n. 2, p. 319-327, 2005. http://dx.doi.org/10.1002/jsfa.1988

GORINSTEIN, S. et al. The total polyphenols and the antioxidant potentials of some selected cereals and pseudocereals. European Food Research and Technology, v. 225, n. 3-4, p. 321-328, 2007. http://dx.doi.org/10.1007/s00217-006-0417-7

HUANG, D.; OU, B.; PRIOR, R. L. The chemistry behind antioxidant capacity assays. Journal of Agricultural and Food Chemistry, v. 53, n. 6, p. 1841-1856, 2005. PMid:15769103. http://dx.doi. org/10.1021/jf030723c

JEONG, S. M. et al. Effect of heat treatment on the antioxidant activity of extracts from citrus peels. Journal of Agricultural and Food Chemistry, v. 52, n. 11, p. 3389-3393, 2004. PMid:15161203. http:// dx.doi.org/10.1021/jf049899k

KORHONEN, H.; PIHLANTO-LEPPALA, A. Food-derived bioactive peptides - Opportunities for designing future foods. Current Pharmaceutical Design, v. 9, n. 16, p. 1297-1308, 2003. PMid:12769738. http://dx.doi.org/10.2174/1381612033454892

LAEMMLI, U. K. Cleavage of structural proteins during the assembly of the head bacteriophage T4. Nature, v. 227, p. 680-685, 1970. PMid:5432063. http://dx.doi.org/10.1038/227680a0

MATTHÄUS, B. Antioxidant activity of extracts obtained from residues of different oilseeds. Journal of Agricultural and Food Chemistry, v. 50, n. 12 , p. 3444-3452, 2002. PMid:12033809. http://dx.doi. org/10.1021/jf011440s

MICHALSKA, A.; CEGLINSKI, A.; ZIELINSKI, H. Bioactive compounds in rye flours with different extraction rates. European Food Research and Technology, v. 225, n. 3-4, p. 545-551, 2007. http://dx.doi.org/10.1007/s00217-006-0452-4

NSIMBA, R. Y.; KIKUZAKI, H.; KONISHI, Y. Antioxidant activity of various extracts and fractions of Chenopodium quinoa and Amaranthus spp. seeds. Food Chemistry, v. 106, n. 2, p. 760-766, 2008. http://dx.doi.org/10.1016/j.foodchem.2007.06.004

ORSINI-DELGADO, M. C.; TIRONI, V. A.; AÑÓN, M. C. Antioxidant activity of amaranth protein and their hydrolysates under simulated gastrointestinal digestion. LWT- Food Science and Technology, v. 44 , n. 8 , p. 1752-1760, 2011.
PAREDES-LÓPEZ, O.; MORA-ESCOBEDO, R.; ORDORICAFALOMIR, C. Isolation of amaranth proteins. LWT - Food Science and Technology, v. 21, n. 1, p. 59-61, 2006.

PÉREZ-JIMÉNEZ, J.; SAURA-CALIXTO, F. Effect of solvent and certain food constituents on different antioxidant capacity assays. Food Research International, v. 39, n. 7, p. 791-800, 2006. http:// dx.doi.org/10.1016/j.foodres.2006.02.003

QUEIROZ, Y. S. et al. Effect of processing on the antioxidant activity of amaranth grain. Archivos Latinoamericanos de Nutrición, v. 9 , n. 4, p. 419-24, 2009.

SAMARANAYAKA, S. G. P.; LI-CHEN, E. C. Y. Food-derived peptidic antioxidants: A review of their production, assessment, and potential applications. Journal of Functional Foods, v. 3, n. 4, p. 229-254, 2011. http://dx.doi.org/10.1016/j.jff.2011.05.006

SCHÄGER, H.; JAGOW, G. V. Tricine-sodium dodecyl sulfatepolyacrylamide gel electrophoresis for the separation of proteins on the range from 1 to $100 \mathrm{kDa}$. Analytical Biochemistry, v. 166, n. 2, p. 368-379, 1987. http://dx.doi.org/10.1016/0003-2697(87)90587-2

SHAHIDI, F. Nutraceuticals and functional foods: whole versus processed foods. Trends in Food Science and Technology, v. 20, n. 9, p. 376-387, 2009. http://dx.doi.org/10.1016/j.tifs.2008.08.004

TARKO, T.; DUDA-CHODAK, A.; TUSZYŃSKI, T. Simulation of phenolic compounds transformation and interactions in an in vitro model of the human alimentary tract. Food Science and Technology International, v. 15, n. 3, p. 235-241, 2009. http:// dx.doi.org/10.1177/1082013208339861

THAIPONG, K. et al. Comparison of ABTS, DPPH, FRAP, and ORAC assays for estimating antioxidant activity from guava fruit extracts. Journal of Food Composition and Analysis, v. 19, n. 6-7, p. 669675, 2006. http://dx.doi.org/10.1016/j.jfca.2006.01.003

TIENGO, A.; FARIA, M.; NETTO, F.M. Characterization and ACEinhibitory activity of amaranth proteins. Journal of Food Science, v. 74, n. 5, p. 121-126, 2009. PMid:19646044. http://dx.doi. org/10.1111/j.1750-3841.2009.01145.x

TIRONI, V. A.; AÑÓN, M. C. Amaranth proteins as a source of antioxidant peptides: Effect of proteolysis. Food Research International, v. 43, n. 1, p. 315-322, 2010. http://dx.doi. org/10.1016/j.foodres.2009.10.001

TSAI, P. J.; SHE, C. H. Significance of phenol-protein interactions in modifying the antioxidant capacity of peas. Journal of Agricultural and Food Chemistry, v. 54, n. 22, p. 8491-8494, 2006. PMid:17061825. http://dx.doi.org/10.1021/jf061475y

VERTUANI, S.; ANGUSTINI, A.; MANFREDINI, S. The antioxidants and pro-antioxidants network: an overview. Current Pharmaceutical Design, v. 10, n. 14, p. 1677-1694, 2004. PMid:15134565. http:// dx.doi.org/10.2174/1381612043384655

WANG, W. Y.; DE MEJIA, E. G. Inhibition of lipid oxidation in cooked beef patties by hydrolysed potato protein is related to its reducing and radical scavenging ability. Journal of Agricultural and Food Chemistry, v. 53, n. 23, p. 9186-9192, 2005. PMid:16277421. http:// dx.doi.org/10.1021/jf051213g

WANG, J. S. et al. Antioxidant properties of papain hydrolysates of wheat gluten in different oxidation systems. Food Chemistry, v. 101, n. 4, p. 1658-1663, 2007. http://dx.doi.org/10.1016/j. foodchem.2006.04.024

ZULUETA, A.; ESTEVE, M. J.; FRÍGOLA, A. ORAC and TEAC assays comparison to measure the antioxidant capacity of food products. Food Chemistry, v. 114, n. 1, p. 310-316, 2009. http://dx.doi. org/10.1016/j.foodchem.2008.09.033 